\title{
Vascular Anatomy of the Subterranean Organ of Ophioglossum vulgatum $\mathrm{L}$.
}

\author{
Hong, Jung HEE") and Woong Young $\mathrm{SOH}^{2)}$
}

1)Department of Biology, Pusan National University, Pusan, 609-735, Korea, 2)Department of Biology, Chonbuk National University, Chonju, 560- 756, Korea.

(accepted September 15, 1993)

\begin{abstract}
The vascular anatomy of subterranean rhizome and root of Ophioglossum vulgatum was studied. The vascular cylinder of the rhizome which had developed adventitiously is ectophloic siphonostele with endarch primary xylem maturation. In the basal part of the rhizome ectophloic siphonostele reveals a complete cylinder of vascular tissue, whereas an ectophloic siphonostele with overlapping gaps occurs in the upper part of the rhizome. Each meristele is arranged as collateral bundle. The bulk of primary xylary elements in the vascular bundles is radially aligned. The roots are monarch with exarch xylem maturation and the monarch vascular pattern reveals opposite arrangement of xylem and phloem. The relation between stelar and total root diameter shows a low correlation. No signs of secondary thickening are found either in the rhizomes or the monarch roots. The comparison of anatomical features of vascular system of the rhizome and root with other ferns shows significant differences.
\end{abstract}

Key words: monarch root, Ophioglossum vulgatum, primary xylem, rhizome, vascular anatomy

Ophioglossaceae is a family of eusporangiate ferns, in which it has been considered to have uncertain origin and taxonomic affinity (Copeland, 1947: Holttum, 1954; Foster and Gifford, 1974; Tryon and Tryon, 1982; Gifford and Foster, 1989). From the features of the Ophioglossaceae and phylogenetic relationship with other groups of ferns, it is assumed that none of the fern families show any sign of affinity with Ophioglossaceae. Wagner(1964) considered the family to be $m$ ore closely related to the Cycadales than to the higher ferns. Some recent studies propose a phylogenetic relationship of the family with the progymnosperm-seed plant line (Bierhorst, 1971; 
White, 1984; Chau, 1986; Kato, 1988; Kato et al, 1988). Studies of morphology and anatomy of Ophioglossum, the most advanced of the genera in the Ophioglossaceae, might not only lead to the establishment of the mature stelar pattern but might also open the way to a new inferences on its evolution and better understanding of the interrelationships among the species. The characters of vascular system seem particularly relevent in this regard. The xylem of Ophioglossum has a suite of characters which is unusual in ferns.

It was reported that the radially seriate xylem which resembles secondary xylem are produced through the activity of a vascular cambium (Campbell, 1911; Bower, 1923; Stevenson, 1980; Chau, 1986), radial seriation of elements, however, is not necessarily an indication of secondary growth. A certain form of primary growth may also produce radially seriate xylem, as has been described by some authors (Esau, 1943, 1965; Thompson and Heimsch, 1964; Soh, 1972). The primary xylem of ferns is useful tissue system in the study of phylogenetic relationships with progymnosperm seed plant line. Ophioglossum generally lack secondary vascular tissue, with the exception of particular organs. Secondary thickening developed in Ophioglossum vulgatum at the periphery of the root xylem and in the stem (Boodle, 1899). A survey of stem protoxylem in Ophioglossum might give an indication of its origin, which so far is unknown, or might lead to new information about xylem evolution in this genus (Webb, 1981).

Previous investigations of vascular organization in the ferns which represents a broad taxonomic and morphological diversity focus mainly on the comparative anatomy of mature stem and consideration on the phylogeny of the stele and the classification of stelar types. It has become apparent that there are developmental and histological dissimilarities among steles of the same type not reflected in the classifications (White, 1984). The partinent literature related to vascular pattern development in the ferns are focused on the cauline or stem influence in the establishment of the mature stelar pattern, or the primary influence which determines xylem differentiation and maturation patterns related to the leaves and their development at the apex (Lucansky and White,1976; Webb, 1981; White, 1984; Chau, 1986). The influences of and interactions among the leaf, shoot and root on vascular pattern establishment and xylem maturation patterns, provide major problems in need of further detailed analysis.

In the present study, we examined the developmental anatomy of the primary vascular system of the subterranean rhizome and root of Ophioglossum vulgatum. Special attention was paid to determine whether ontogenetic change in stelar patterns is shown and whether the vascular tissue is indeed primary for the mature sporophytes.

\section{Materials and Methods}

Sporophytes of Ophioglossum vulgatum L. were obtained from mature plants that had been grown in the Cheju islands during May-June. Rhizomes and roots were fixed in FAA, dehydrated with a tertiary butyl alcohol series, and embedded in paraffin according to techniques described by Berlyn and Miksche(1976). The paraffin blocks 
were sectioned transversely at $10 \mu \mathrm{m}$ on a rotary microtome. Sections were stained with a combination consisting of hematoxylin, safranin and light green. From the serial sections anatomical structure of the vascular tissue and the ontogenetic changes in stelar patterns were examined. Measurements of transverse sections were made with an ocular disk micrometer calibrated with a stage micrometer.

\section{Results and Discussion}

\section{Morphology}

The mature sporophytes collected in the field consist of a short globose rhizome, roots and a single frond. Each leaf consists of a simple sterile segment and a compact spikelike fertile segment. Under natural conditions usually only a single frond arise from a subterranean stem each growing season. The leaf is simple and entire. The venation of the blade is reticulate and there is no distinct midrib. It has been suggested that simple leaves are reduced rather than primitive in these ferns (Bold et al., 1987). In most plants, there is a horizontal root present at the base of the rhizome. Adventitious roots occur frequently on the short, upright stem. Vegetative propagation by adventitious rootborne buds is general, thus new shoots take their origin from roots. Attention has often been drawn to the morphological similarities between $O$. vulgatum and $O$. reticulatum. d'Almedia(1922) considered that these two are merely forms of the same species, being connected by a number of transitional stages, whereas Nishida(1957) considered that $O$. vulgatum might simply be a small type of $O$. reticulatum. The two species can be separated on the basis of their epidermal and spore characters (Nishida, 1959; Mahabale, 1962).

Anatomy of the shoot

In transverse section the vascular cylinder seems to be in the form of a distinct ring and there is histological evidence of an endodermis and pericycle in mature rhizomes. A transverse section just below the level of the shoot apex reveals that a young pith and procambial strands are differentiated (Fig. 1). Further down the cylindrical vascular system is established (Fig. 2-4). Primary phloem cells differentiate first in the outmost portion of the procambium. The final maturation of phloem progresses acropetally into and through the strand from its basal part. In addition to the acropetal wave of maturation, there is a centripetal progression and the primary phloem forms a continuous system throughout its development. Slightly later than phloem protoxylem arises in the innermost part of the procambium. Xylem differentiates very close to the apex of the shoot. Subsequent maturation of metaxylem progresses outward through the procambial cylinder. Xylem differentiation proceeds bidirectionally at young leaf base, ultimately establishing a continuity with the mature system (Fig. 5-7). Thus, the primary xylem system, although continuous when mature, is discontinuous during development. Proximal to the third internode on the mature shoot, the mature metaxylem of the stele 
obscures the details of the protoxylem patterns. The bulk of the xylem elements is radially seriate. Internodal xylem strands relatively delicate. The number of internodal vascular strands varies considerably from two to five, even on different regions of the same internode. A transection within a third internode show $s$ three vascular bundles and at this level, primary phloem and xylem are fully differentiated (Fig. 3 ). In the fern a variety of pattern of differentiation has described. White(1984) has reported that some of the proxylem strands extend acropetally beyond the youngest leaf primordia and therefore develop in a different way. In the Osmunda cinnamomea, a acropetal wave of xylem differentiation meets the basipetal wave of protoxylem in the leaf trace (Steeves, 1989).

A transection at the basal part of the stem reveals a complete cylinder of vascular tissue and in the center the phloem only surrounds the xylem externally to form a ectophloic siphonostele (Fig. 5). The center of the xylem shows the appearance of a parenchymatous mass, which becomes more conspicuous further up to form siphonostelic structure. Above stem base the closed cylinder of vascular tissue is perforated by the presence of a leaf gaps (Fig. 6, 7). The cylinder again appears closed within the next higher internode (Fig. 4). However, it is noted that the vascular cylinder in the upper part of stem above the third internode is much dissected into discrete strands and reveals an ectophloic siphonostele with overlapping leaf gaps (Fig. 1-3). The shortness of the internodes and the overlapping of the leaf gaps result in dissection of the stele, which is a network of anastomosing and dividing strands around the pith. The stele is further characterized by bundles that either begin or end differentiation in the gaps. It $w$ as clearly seen in the basal part below the level of the first leaf gap, that the pith is ontogenetically intraxylic in origin, and the siphonostele develops from the protostele by the formation of inner initials of the tracheary elements into parenchyma initials (Bower, 1923). Parenchyma cells are mingled with tracheids and the number of parenchyma cells are seen to increase in an upwards direction.

Each meristele is arranged as an collateral bundle and endarch axial bundles in which protoxylem is on the inner side of each bundle next to the pith. This part of the stele corresponds to the definition of eustele as initially Brebner (1902). The term eustele has no phylogenetic connotation and is used to denote a stele which in cross section contains collateral bundles in a single ring around the pith. Furthrer support are provided by Kato(1988), who proposed that the stelar pattern of Ophioglossaceae is eustele. Research on stelar anatomy of $O$. Iustitanicum (Gewirtz and Fahn, 1960) and $O$. reticulatum (Sen, 1968) shows that the stele of rhizome of the sporophyte is protostelic structure at the basal part and siphonostelic in its upper portion. Further up, because of the overlapping of several gaps, the vascular tissue breaks up into several meristeles to reach the dictyostelic condition.

Bower (1911), who studied medullation in young plants of Ophioglossum spp., found a pith present throughout the rhizomes of adventitious origin, while some of the non-adventitious shoots of the same species were protostelar in their lower most zone. He states that presence or absence of a pith may be controlled by nutritional factors. In 
the rhizomes investigated by us, which had presumably developed adventitiously, siphonostele was found in their basal part. Sporne (1962) considered ectophloic siphonostele without leaf gaps as a protostele and it is termed a medullated protostele. Sporne does not use the term siphonostele for the Pteridophyta.

The stem base of $O$. petiolatum contains an exarch protostele that changes to a mesarch siphonostele (Webb, 1975; 1981). These same ontogenetic changes in stelar patterns have shown for the young sporophytes of tree ferns (Gwynne-Vaughan, 1903; Stephenson, 1907; Wardlaw, 1945; Lucansky and White, 1976). The stele pattern which reveals a protostele in the earliest ontogenetic stages represents the primitive type of vascular patterns in ferns (Gwynne-Vaughan, 1903; Stephenson, 1907; Wardlaw, 1945). The changes from protostele to siphonostele is variable and is dependent upon conditions and rapidity of growth (Gwynne-Vaughan, 1903; Stephenson, 1907).

The present study reveals that the basal region shows a definite cauline stele, which in the upper part it is impossible to distinguish the cauline from the foliar strands. Protoxylem patterns appear to be clearly associated with leaf vascularization in ferns and seed plants, and the development of metaxylem and the cauline strands in ferns provide a broad array of problem s to be solved by researchers. Stevenson's (1980) work mapping the course of the protoxylem strands in Botrychium multifidum indicates that the protoxylem strands are arranged as sympodium and that the entire system resembles the eusteles of progymnosperm and seed plants. This is consistent with the finding of eustelic pattern in Ophioglossum (Chau, 1981).

The bulk of the xylem elements in the vascular bundles is radially aligned, whereas radially seriate phloem is not observed. No secondary xylem is produced. Secondary growth is unknown in extant Pteridophytes with the exception of Botrychium, but it existed in fossil forms. Ophioglossum and Helminthostachys, specialized genera of Ophioglossaceae, generally lack secondary vascular tissue, although it is found vestigially in a particular organs. Boodle(1899) found developing secondary tracheids at the periphery of the root xylem in Ophioglossum vulgatum. Secondary xylem was produced in the stele of a branched stem with a wounded apex of Helminthostachys (Lang, 1915). The fact suggests that these genera might have almost entirely lost cambial activity during the course of phylogenetic specialization(Kato, 1987). Recently, Chau(1986) reported that, in Botrychium dissectum, secondary xylem and cambial activity differs from that found in progymnosperm and seed plants in not producing secondary phloem. Botrypus virginianus, which is one of the most primitive species in Ophioglossaceae, have been described as having secondary xylem, vascular cambium and periderm (Takahashi and Kato, 1988). Further comparative study on the anatomy of the Ophioglossaceae may shed light on the significance of these features and requires a broader sampling than has been accomplished thus far.

Anatomy of the root

Roots arise acropetally, as has been reported for O. petiolatum and $\mathrm{O}$. crotalophoroides (Webb, 1981). Transections of the mature roots show that the 
epidermis, devoid of root hairs, is uniseriate and is heavily suberized on its outer walls(Fig. 8A). Outer cortex consists of angular cells without intercellular spaces, while inner cortex is com posed of oval cells with intercellular spaces. All the cortical cells are packed with starch grains. The inner limit of the cortex is a clearly defined endodermis. The solid xylem strand is monarch and shows roughly crescentic in section (Fig. 8B). The monarch vascular arrangement reveals opposite arrangement of xylem and phloem. The earliest maturing cells are external to those which mature later and therefore an exarch xylem maturation pattern exists. The protoxylem of the root easily distinguished from the metaxylem in transverse section by the conspicuous difference in cell diameter. Phloem elements aligned radially, extend over its concave side. No sign of secondary thickening were found in the monarch roots. The root at different regions from base to apex shows a uniform pattern of vascular tissue differentiation(Fig.9). The structural changes between the large-diameter root and smaller-diameter root were not observed.

Campbell (1911) and Bower (1930) reported that almost all the species of the EuOphioglossum have monarch roots. In Ophioglossum, however, the root may be monarch, diarch, or tetrarch. Vasisht (1927) found diarch to tetrarch roots in O. fibrosum. It is most often triarch in $O$. engelmannii (Chrysler, 1941). Monarch roots are found in $O$. Iusitanicum (Gewirtz and Fahn, 1960) and O. reticulatum(Sen, 1968). Maheswari and Singh(1934) reported diarch roots in $O$. vulgatum, but not a single specimen examined in this study confirmed their observation. It has been shown that the number of vascular strands may be constant in any given plant and may be quite characteristic of a species, genus, or even families. In some plant groups the number of vascular strands varies among members of the group or varies within the root of the same individual (Heimsch, 1951; Torrey, 1955).

The Relation of stele diameter to root diameter

In transection of the root primary vascular tissue of monarch root range from 49.3$57.5 \mu \mathrm{m}$ in diameter(Table 1). The total root diameter are 242-308 $\mu \mathrm{m}$. Analysis of individual vascular tissue reveals that the increase in cell size is gradual. From the results of diameters of stele and total root it can be concluded that the increase in stelar diameter is accomodated, in part, by an increase in the root diameter. In roots of comparable morphological status, the level at which tissue mature depends largely upon the size of the root and its growth rate. An increase in diameter of incense cedar root was accompanied by an increase in number of cells in both the cortex and the stele(Wilcox, 1962a). It was thought that variation in tissue differentiation would relate more closely to growth rate than to possible differences in root diameter with a root order(Wilcox, 1962b).

A stele which was $3.49 \%$ of the total root cross- sectional area was encountered in the basal portion of a root $308 \mu \mathrm{m}$ in diameter. On the other hand, a stele with a 4.15 $\%$ cross-section area ws found in the apical portion of a root $242 \mu \mathrm{m}$ in diameter. In general, in the apical portion of a root the stele represents a larger percentage of the root cross-sectional area in the basal portion of a root. Wilcox(1962b) found that in the 
smaller root the stele showed a larger percentage of the root cross-sectional area than in the larger root. In roots studied, the cross-section area of the stele remained relatively small. The results suggest that the relation between root diameter and stelar diameter shows a low correlation.

Table 1. Measurements of roots at different regions showing the transverse dimensions of the mature primary tissues in Ophioglossum vulgatum

\begin{tabular}{lclc}
\hline \hline Region & $\begin{array}{c}\text { Diameter of stele } \\
(\mu \mathrm{m})\end{array}$ & $\begin{array}{l}\text { Total root } \\
\text { diameter }(\mu \mathrm{m})\end{array}$ & $\begin{array}{l}\text { Cross-sectional } \\
\text { area of stele }(\%)\end{array}$ \\
\hline base & $57.5 \pm 2.3$ & $308 \pm 12.0$ & 3.49 \\
middle & $49.5 \pm 1.5$ & $306 \pm 4.0$ & 2.62 \\
apex & $49.3 \pm 2.2$ & $242 \pm 3.5$ & 4.15 \\
\hline \hline
\end{tabular}

It was reported that the changes in root diameter were accompanied by changes in numbers of protoxylem group in pea and incense cedar roots (Torrey, 1957; Wilcox, $1962 \mathrm{~b})$. There are a lack of correlation between the number of protoxylem positions and various physical measurements such as width of apical initial zone or diameter of stele at the time of pattern formation (Torrey, 1957; Wilcox, 1962b), while a close relationship between the size of the procambial cylinder and vascular complexity (number of xylem groups) has been demonstrated in some grass roots(Feldman and Torrey, 1975; Charlton, 1980; Barlow and Rathfelder, 1984). It seems quite likely that the variation in growth activity and root anatomy are probably under hormonal control. Further elucidation on the possible nature of growth control in fern root will be required and these studies should be described in terms of root morphogenesis and differentiation.

\section{Acknowledgement}

The authors thank Dr. K.D. Kang for his technical assistance. The work was supported by the Basic Science Research Institute Program (BSRE-92-427) from the Ministry of Education of Korea.

\section{References}

Barlow, P.W . and L . Rathfelder. 1984. Correlations between the dimensions of different zones of grass root apices, and their implications for morphogenesis and differentiation in roots. Ann. Bot. 53: 249-260.

Berlyn, G.P. and J.P. Miksche. 1976. Botanical Microtechnique. McGraw-Hill Pub., New York.

Bierhorst, D.W . 1971. Morphology of Vascular Plants. Macmillan, New York. 
Bold, H.C., C.J. Alexopoulos and T. Delevoryas. 1987. Morphology of Plant and Fungi, Harper and Row, New York.

Boodle, L.A. 1899. On some points in the anatomy of Ophioglossaceae. Ann. Bot. 13: 377-394.

Bower, F.O. 1911. On the primary xylem and origin of medullation in the Ophioglossum. Ann. Bot. 25: 537-555.

Bower, F.O. 1923. The Ferns. Vol. I. Cambridge University Press . London .

Bower, F.O . 1930. Size and Form in Plants. Macmillan and Co. London.

Brebner, G. 1902. On the anatomy of Danaea and other Marattiaceae. Ann. Bot. 16:517-552.

.Campbell, D.H. 1911. The Eusporangiate. Carnegie Inst. Washington Publ. No. 140. Washington, D.C.

Charlton, W.A., 1980. Primary vascular patterns in root meristems of Pontederia cordata and their relevance to studies of root development. Can. J. Bot. 58: 1351-1369.

Chau, R. 1981. Vascular morphology in the Ophioglossaceae. Ph.D . thesis, Univ. of Michigan, Ann Arbor.

Chau, R .I. 1986. Xylem structure in Botrychium dissectum Sprengel and its relevance to the taxonomic position of the Ophioglossaceae. Am. J. Bot. 73: 1201-1206.

Copeland, E.B. 1947. Genera Filicum. Chronica, Botanica, Waltham .

Chrysler, M.A. 1941. The structure and development of Ophioglossum palmatum. Bull. Torrey Bot. Club 72: 491-505.

D'Almedia. J.F.R. 1922. The Indian Ophioglossums. J. Indian Botan. Soc. 3: 5865.

Esau, K. 1943. Origin and development of the primary vascular tissue in seed plants. Bot. Rev. 9: 125-206

Esau, K. 1965. Plant Anatomy, 2nd ed. Wiley and Sons, Inc., New York.

Feldman, L.J. and Torrey, J.G. 1975. The quiescent center and primary vascular tissue pattern formation in cultured roots of Zea. Can. J. Bot. 53: 2796-2803.

Foster, A.S . and E.M . Gifford, Jr. 1974. Comparative Morphology of Vascular Plants. 2nd ed. John W iley and Sons, New Y ork.

Gewirtz, M. and A. Fahn, 1960. The anatomy of the sporophyte and gametophyte of Ophioglossum lusitanicum L. ssp lusitanicum. Phytomorphology 10: 342-351.

Gifford, E.M . and A .S . Foster. 1989. Morphology and Evolution of Vascular Plants. 3rd ed. W .H. Freeman and Company, New York.

Gwynne-Vaughan, D.T. 1903. Observations on the anatomy of solenostelic ferns. Part II. Ann. Bot. 17: 689-742.

Heimsch, C. 1951. Development of vascular tissues in barley roots. Am. J. Bot. 38 : 523-537.

Holttum, R.E. 1954. A Revised Flora of Malaya. Vol II. Fems of Malaya. Governm. Print.

Kato, M . 1987. A phylogenetic classification of Ophioglossaceae. Gard. Bull. Singapore 40: 1-14. 
Kato, M . 1988. The phylogenetic relationship of Ophioglossaceae. Taxon 37:381386.

Kato, M ., A . Takahashi and R . Imaichi. 1988. Anatom y of the axillary bud of Helminthostachys zeylanica(Ophioglossaceae) and its systematic implication. Bot. Gaz. 149: 57-63.

Lang, W.H. 1915. Studies in the morphology and anatomy of the Ophioglossaceae. III. On the anatomy and branching of the rhizome of Helminthostachys zeylanica. Ann. Bot. 29:154.

Lucansky, T.E . and R.A. White. 1976. Comparative ontogenetic studies in young sporophytes of tree ferns. I. A primitive and an advanced taxon. Am. J. Bot. 63: 463-472.

Mahabale, T.S. 1962. Species of Ophioglossum in India. Bu11. Botan. Surv. India 4: 71-84.

Maheswari, P. and B. Singh. 1934. The morphology of Ophioglossum fibrosum Schum. J. Indian Botan. Soc. 8: 103123.

Nishida, M. 1957. Studies on the systematic position and constitution of Pteridophyta. J. Coll. A rts. Sci. Chiba University, Japan 2: 179-211.

Nishida, M. 1959. Studies on the systematic position and constitution of Pteridophyta. Bull. Natl. Sci. Museum, Tokyo, 44:328.

Sen, U. 1968. Morphology and anatomy of Ophioglossum reticulatum. Can. J. Bot. 46: 957- 968.

Soh, W .Y. 1972. Early ontogeny of vascular cambium. I. Ginkgo biloba. Bot. Mag. Tokyo 85: 111-124.

Sporne, K.R. 1962. The morphology of Pteridophytes. Hutchinson Univ. Library, London.

Steeves, T.A. and I.M. Sussex. 1989. Patterns in Plant Development . Cambridge Univ . Press, Cambridge .

Stephenson, G.B. 1907. Young stages of Dicksonia and Cyathea. Trans. New Zeal. Inst. 40: 1- 16.

Stevenson, D.W . 1980. Ontogeny of the vascular system of Botrychium multifidum (Ophioglossaceae) and its bearing on stelar theories. Bot. J. Linn. Soc. 80: 41-52.

Takahashi, A . and M . Kato. 1988. Developmental anatomy of vascular cambium and periderm of Botrypus virginianus and its bearing on the systematic position of Ophioglossaceae. Bot. Mag. Tokyo 101: 373-385.

Thompson, N .P. and C . Heimsch. 1964. Stem anatomy and aspects of development of tomato. Am. J. Bot. 51:7-19.

Torrey, J.G. 1955. On the determination of vascular patterns during tissue differentiation in excised pea roots. Am. J. Bot. 42: 183-198.

Torrey, J.G. 1957. Auxin control of vascular pattern formation in generating pea root meristems grown in vitro. Am, J. Bot. 44: 859-870.

Tryon, R.M . and A. F. Tryon. 1982. Ferns and Allied Plants with Special Reference to Tropical America. Springer-Verlag, New York. 
Vasisht, B.R. 1927. The comparative anatomy of Ophioglossum aitchisonii d'Almeida and Ophioglossum vulgatum L . J. Indian Botan. Soc. 6: 8-30.

Wagner, W .H. Jr. 1964. Evolutionary patterns of living ferns. Mem. Torrey Bot. Club 21: 86-95.

Wardlaw, C.W . 1945. Experimental and analytical studies of Pteridophytes. V. Stelar morphology: The development of the vascular system. Ann. Bot. N.S. 9: 217-233.

Webb, E. 1975. Stem anatomy and phyllotaxis in Ophioglossum petiolatum. Am. Fern J. 65: 87-94.

Webb. E. 1981. Stem anatomy, phyllotaxy, and stem protoxylem tracheids in several species of Ophioglossum . I. O. petiolatum and O. crotalophoroides. Bot. Gaz. 142: 597-608.

White, R. A. 1984. Comparative development of vascular tissue patterns in the shoot apex of ferns. In: Contemporary Problems in Plant Anatomy, Edited by R.A. White and Dickison W .C . pp 53-107, Academic Press, New York .

Wilcox, H . 1962a. Grow th studies of the root of incense cedar, Libocedrus decurrens. I. The origin and development of primitive tissues. Am. J. Bot. 49: 221-236.

Wilcox, H. 1962 b. Growth studies of the root of incense cedar, Libocedrus decurrens. II. Morphological features of the root system and growth behavior. Ann. J. Bot. 49:237-245.

Figs. 1-4. Serial transverse sections of Ophioglossum vulgatum rhizomes. Fig. 1. Procambial stage of differentiation at first internode. Fig. 2. Vascular cylinder at second internode showing early stages of vascular tissue differenliation. Note proxylem maturation and lack of radially aligned elements. Fig. 3. Vascular cylinder at third internode showing more extensive development of primary phloem and xylem. Fig. 4. Vascular cylinder below the third internode show ing slightly radially aligned xylem. Note ectophloic siphonoslele composed of a complete cylinder of vascular tissue withoul leaf gaps.

All X200. PC, procambium; P, primary phloem; PX, protoxylem; MX, metaxylem . 


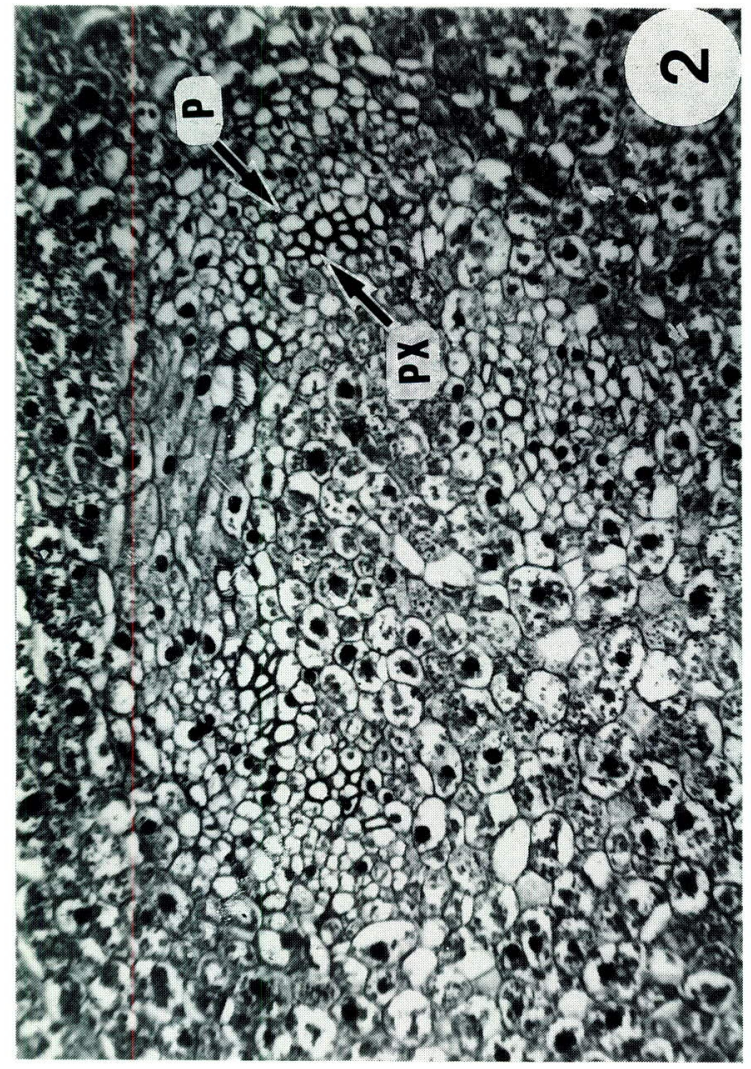

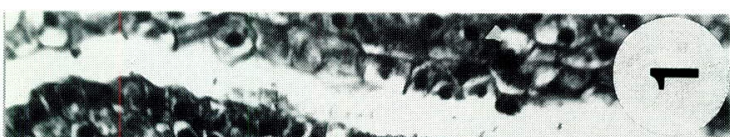

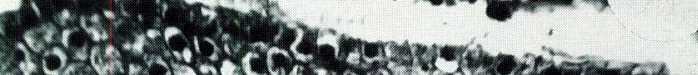

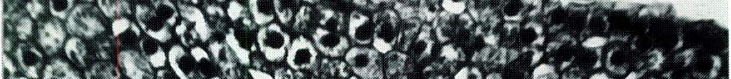

Ho

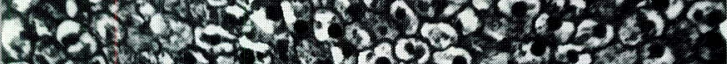
sto

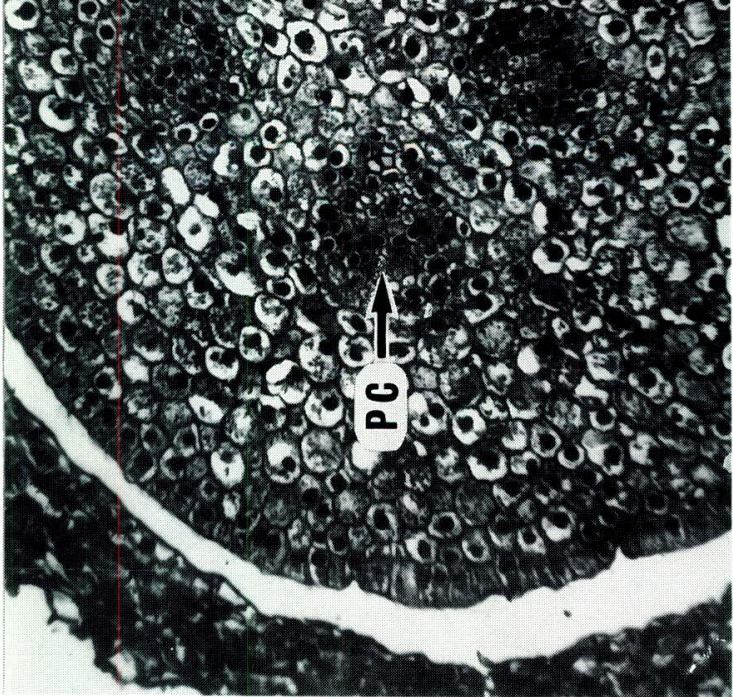

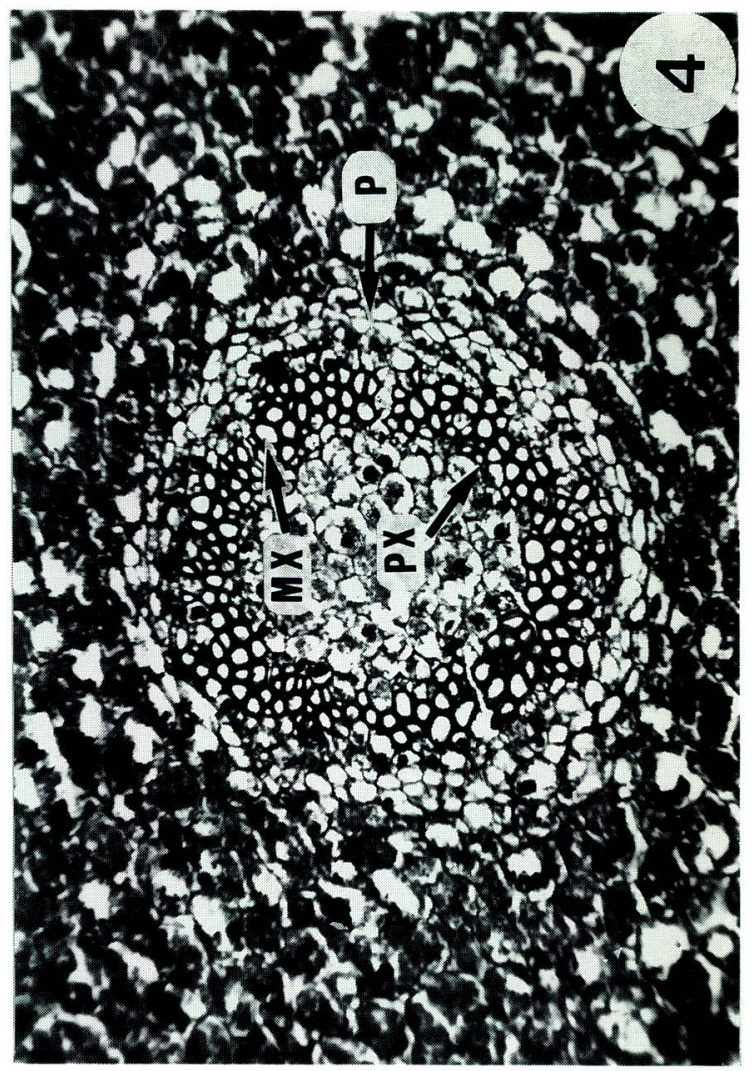

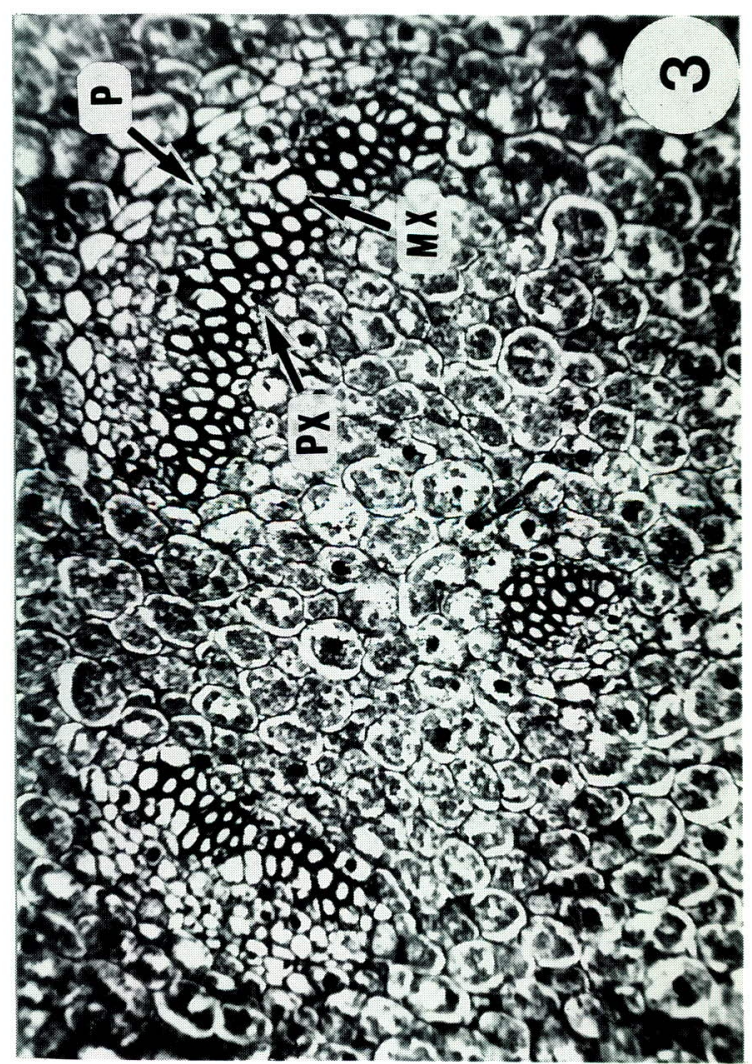



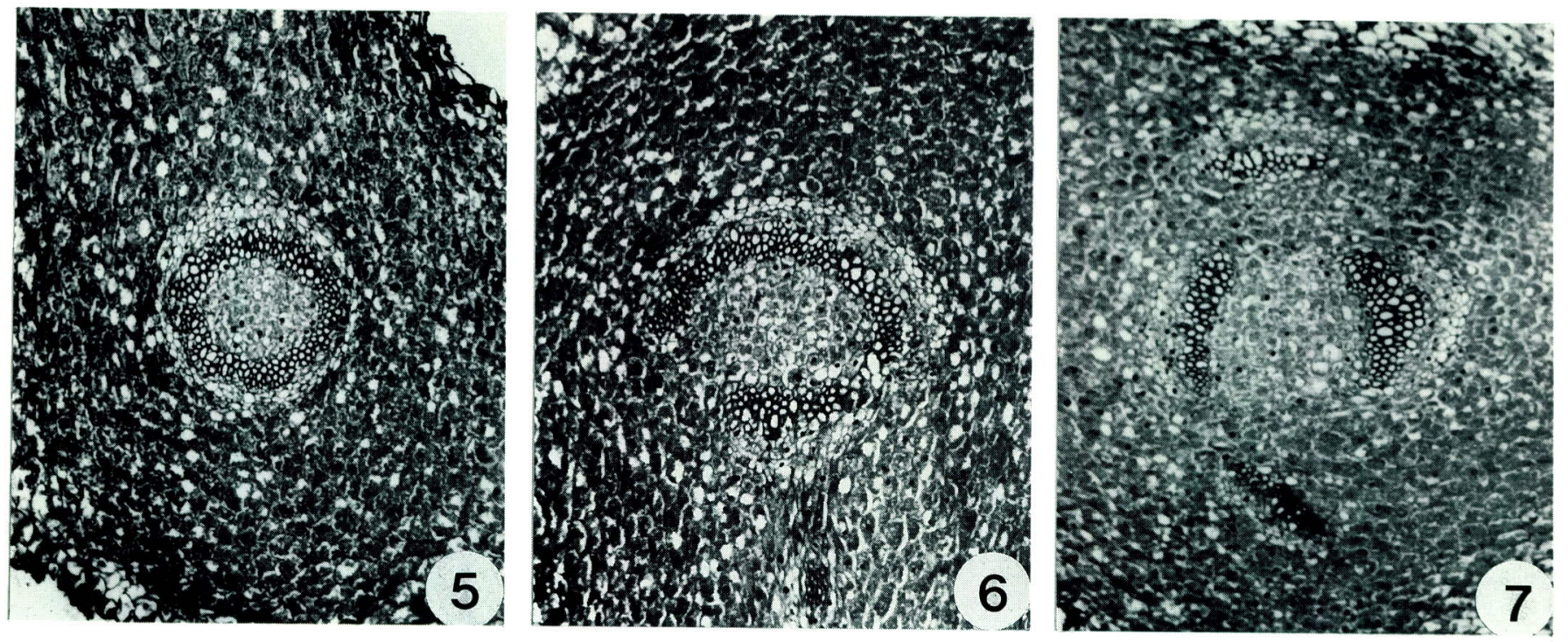

Figs. 5-7. Serial transverse section within a fourth internodal region of a rhizome from base upward, showing progression from a siphonostele composed of closed vascular cylinder to a siphonostele $w$ ith overlapping leaf gaps. Fig. 5. Level at basal part of a rhizome. Note complete cylinder of vascular tissue with pith. Fig. 6. Level higher than Fig. 5. The stele opens and vascular cylinder perforated by a leaf gap. Fig. 7. Level higher than Fig. 6. Note ectophloic siphonostele with overlapping of several gaps and meristeles. All x100.


Fig. 8. Transverse sections of a root of Ophioglossum vulgatum. A, section of a root showing thick cortex, endodermis and monarch xylem. $x 100$. Bar $=50$ um. B, details in monarch stele. x200. P, primary phloem; PX, protoxylem, MX, metaxylem. 

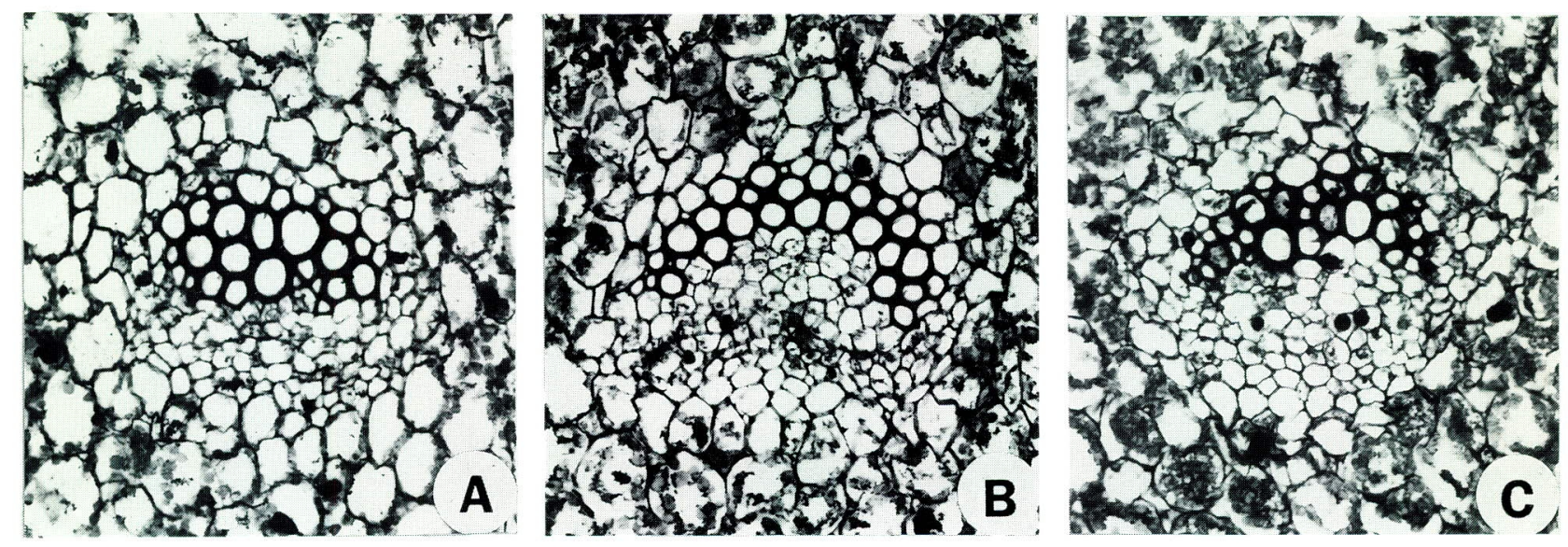

Fig. 9. Transverse sections of a root from basal region to apical region, showing uniform pattern of vascular tissue differentiation. x200. A, basal region; $B$, middle region; $\mathrm{C}$, apical region. 